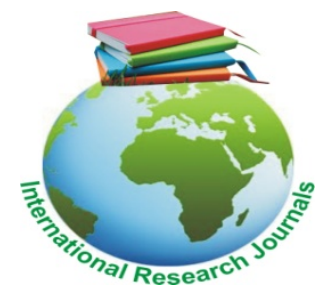

African Journal of Food Science and Technology (ISSN: 2141-5455) Vol. 6(4) pp. 098-107, July, 2015

Available online @http://www.interesjournals.org/AJFST

DOI: http:/dx.doi.org/10.14303/ajfst.2015.041

Copyright @2015 International Research Journals

Full Length Research Paper

\title{
Detection of heavy metals bio-accumulation in scombrids for the determination of possible health hazard
}

\author{
Vishwakalyan Bhoyroo, Naajiyah Soobratty and Bhanooduth Lalljee \\ Department of Agricultural And Food Sciences Faculty of Agriculture University of Mauritius Reduit Mauritius \\ Corresponding email:v.bhoyroo@uom.ac.mu
}

ABSTRACT

\begin{abstract}
Concentrations of trace elements zinc, copper, nickel, chromium and heavy metals lead, mercury, cadmium and arsenic were detected in the muscle tissues of four commercially edible fishes belonging to the scombridae and related families including yellow fin tuna (Thunnus albacares), Dogtooth tuna (Gymnosarda unicolor), Marlin (Makaira mazara) and the dolphin fish (Coryphaena hippuru) in the EEZ (Exclusive Economic Zone) of Mauritius. The concentrations were within the range 1.34-10.03, 0.0-1.42, $0.23-0.89,0.0-2.43,0.0,3.60-5.44,0.03-0.13$ and $0.03-0.07 \mathrm{mg} / \mathrm{kg}$ wet weight respectively for summer and winter seasons. Inter-species variations with respect to elemental accumulations were not significantly different as compared to seasonal variations for the accumulation of chromium, zinc and lead. Marlin and Dorado caught during the summer season exceeded the authorised level of chromium in muscle tissues according to international standards. A survey carried out among fish consumers in Mauritius revealed that $80 \%$ of the respondents were ignorant about heavy metal bio-accumulation.
\end{abstract}

Keywords : Mauritius, muscle tissues, heavy metals, yellow fin tuna, Dogtooth tuna, Marlin, Dorado

\section{INTRODUCTION}

Heavy metals pollution in the marine ecosystems is a result of anthropogenic activities such as mining, shipping, agriculture and domestics (Haynes \& Johnson, 2000; Islam \& Tanaka, 2004). Humans as well as aquatic organisms are under the threat of a rise in heavy metals concentration in the marine environment (Uluturhan et al., 2007; Naji et al., 2010; Bashir et al., 2013). In the last few decades, fishes have been the subject of various studies around the world due to their ability to bioaccumulate heavy metals (EInabris et al., 2013). In an attempt to reduce possible human health hazards, commercially edible fish species are favoured for studies since the diet is the main route of human exposure to heavy metals (Türkmen et al., 2005; Tepe et al., 2008; Raja et al., 2009; Alina et al., 2011; Kumar et al., 2012).

Heavy metals that are classified as harmful toxic substances are mercury, arsenic, lead and Cadmium among others. Mercury is considered as one of the most dangerous toxic heavy metal that can have adverse effects on human health. Lead and arsenic affects the reproductive system of women, by displaying toxicity towards the growing foetus (Goeringa et al., 2010) while cadmium builds up in the placenta (Berlin et al., 1992; Moberg et al., 1992; Jarup et al., 1998). Trace elements such as Zinc, Copper, Nickel and Chromium are present in low amount and are important in the human body system (Fraga et al., 2005). However, if present in excess, they acquire toxic properties depending on the absorption, concentration and persistence at their action points (Shanker, 2008)

In the island of Mauritius with an Exclusive Economic Zone (EEZ) of around 1.9 million $\mathrm{km}$, the previous Minister of Fisheries, Nicolas Von-Mally predicted a bloom in the Seafood Hub with investments ranging from Rs 30 billion to Rs 40 million ( Business Mega, 2014 ). Local sea food consumption in Mauritius per capita is 
estimated to be around $20 \mathrm{~kg}$ (Business Mega, 2012). The Scombridea is a family of epipelagic marine fishes comprising of the mackerels, tunas and bonitos. Scombrids are active predators which are found at the highest tropic level of the aquatic food chains (Colette et al., 1983).FADs (Fish Aggregating Devices) in Mauritius catch around 288 tons of scombrids annually where albacares tuna is most frequently caught.

These fishes of the Scombridae and related families possess bioaccumulation capacities as they are at the top of the trophic levels of the aquatic food chains (Kojadinovic et al., 2006) and are important commercially edible fishes. These criteria make the fish species belonging to the scombridae and related families the best candidates for the detection of the levels of heavy metals in their muscle tissues which can thus can be used to ensure food supply safety and diminish any potential risk of health hazard for the population.

International government agencies such as the JEFCA (The Joint FAO/WHO Expert Committee on Food Additives), the World Health Organisation (WHO), the MAFF (Ministry of Agriculture, Fisheries, and Food) and the Mauritian Food act 1998 have proposed MPL (Maximun permissible level) of trace elements in the human diet as safety regulations and to be used as comparison standards.

The aim of this research is based on the detection of the levels of trace elements such as $\mathrm{Zn}, \mathrm{Cu}, \mathrm{Cr}, \mathrm{Ni}$ and heavy metals such as $\mathrm{Hg}, \mathrm{Cd}, \mathrm{Pb}$, As using AAS (Atomic Absorption Spectrophotometer) techniques in muscle tissues of four commercially edible fish species belonging to the scombridae and related family namely the yellowfin tuna (Thunnus albacares), Dogtooth tuna (Gymnosarda unicolor), Marlin (Makaira mazara) and the dolphin fish (Coryphaena hippuru) during the summer and winter seasons to assess their potential health hazard for the Mauritian population.

\section{MATERIAL AND METHODS}

\section{Sample Collection}

Fresh samples were collected from local markets and coastal fish landing stations, after careful identification based on morphological key characteristics ( Table 1.0). three Ventral slices from different fishes of the same species were sectioned and sealed in polyethene bags. The fish samples were approximately of the same ventral diameter, ranging from 19 to $21 \mathrm{~cm}$ width. The samples were then placed in an ice bag and bought to laboratory. The sampling procedures were repeated several times in the different locations to obtain three replicates of each fish species for both winter and summer seasons.

\section{Sample processing (Dry ashing procedure)}

All glasswares and equipment were soaked in $10 \%$ nitric acid overnight, rinsed with deionised water and dried in a drying cabinet prior use. A freeze dryer was run overnight to dry the fish muscles. The samples were then placed in acid washed jars, tightly sealed with paraffin and placed in a desiccator to prevent absorption of moisture.

The dried samples were crushed into powder by using motor and pestle. 2 grams of each sample were then placed in a $25 \mathrm{ml}$ crucible. This process was duplicated so that each fish sample obtained a replicate and placed into a muffle furnace at $500{ }^{\circ} \mathrm{C}$ for approximately 8 to 10 hours .After the samples have been ashed, $2 \mathrm{ml}$ of concentrated nitric acid were placed in each crucible and cautiously swirled. Following this, the samples were placed in a sand bath at $68{ }^{\circ} \mathrm{C}$. The samples which were then placed back into the muffle furnace at $500{ }^{\circ} \mathrm{C}$ for another 2 hours. Once the crucibles were cooled at room temperature, $10 \mathrm{ml}$ of $\mathrm{IM} \mathrm{HCl}$ were added in each crucible, swirled and made up to the mark in a $25 \mathrm{ml}$ volumetric flask.

\section{Metal detection}

Levels of the different heavy metals $(\mathrm{Zn}, \mathrm{Cu}, \mathrm{Ni}, \mathrm{Hg}, \mathrm{As}$, $\mathrm{Pb}, \mathrm{Cd}, \mathrm{Cr}$ ) were measured using the AAS. Each metals was detected at a specific wavelength and using a specific lamp. For the metals $\mathrm{Zn}, \mathrm{Cu}, \mathrm{Ni}$, and $\mathrm{Cr}$ the apparatus was calibrated as those metals are normally detected through flame atomic absorption spectroscopy in parts per millions (ppm). $\mathrm{Cd}, \mathrm{Pb}$ and As were detected using the graphite atomic absorption spectrophotometer, where the results were indicated in parts per billions $(\mathrm{ppb})$ while $\mathrm{Hg}$ was detected using flameless AAS also known as AAS hydride in ppb.

\section{Population survey}

To determine population awareness about the implications of heavy metals in fish as well as their consumption patterns, a mini survey was conducted. The sampling frame used was the stratified sampling with 10 participants from each central local market. The questionnaires were distributed near the fish stall section. The questions were processed and analysed using the SPSS 20.0 software.

\section{RESULTS \& DISCUSSION}

Cadmium was not detected in any fish samples and there is no significant difference between the bioaccumulation of all the detected trace elements with respect to the species (Table 2). Different fish species did not accumulate significantly different amount of trace elements in their muscle tissues $(P<0.05)$. The levels of zinc, chromium and lead accumulated in muscle tissues of the four fish species are significantly different for the summer and winter seasons $(p<0.05)$ while no significant difference in the accumulation patterns was 
Table 1. Identification features of the four different fish species

\begin{tabular}{|c|c|c|c|c|}
\hline Species & & Skin colour & Flesh type & General morphology \\
\hline fin Tuna & Yellow & $\begin{array}{l}\text { Metallic grey; yellow and silver } \\
\text { on belly area }\end{array}$ & Reddish brown & $\begin{array}{l}\text { Largest near middle of first dorsal } \\
\text { base }\end{array}$ \\
\hline $\begin{array}{l}2 . \\
\text { tuna }\end{array}$ & Dogtooth & Silver or white flanks and belly & White and scale less & Short pectoral fins and big heads \\
\hline $\begin{array}{l}3 . \\
\text { fish }\end{array}$ & Dolphin & $\begin{array}{l}\text { Pectoral fins are iridescent blue. } \\
\text { The flank is broad and golden }\end{array}$ & White & $\begin{array}{l}\text { Entire bodies are compressed } \\
\text { and comprises of single dorsal } \\
\text { fins extending from the head to } \\
\text { the tail( Dianne, 2011) }\end{array}$ \\
\hline 4. & Marlin & Metallic grey & Pinkish & $\begin{array}{l}\text { Short dagger like structure at } \\
\text { front }\end{array}$ \\
\hline
\end{tabular}

Table 2. Two Way ANOVA ( $p$ value) for the different trace elements

\begin{tabular}{|c|c|c|c|c|}
\hline \multicolumn{5}{|c|}{ Significant difference ( $p$ value ) } \\
\hline Trace element & Species & Seasons & $\begin{array}{l}\text { Seasons } \\
\text { Species }\end{array}$ & \& \\
\hline Zinc & 0.515 & 0.00 & 0.968 & \\
\hline Copper & 0.238 & 0.906 & 0.436 & \\
\hline Nickel & 0.376 & 0.758 & 0.192 & \\
\hline Chromium & 0.101 & 0.022 & 0.112 & \\
\hline Cadmium* & - & - & - & \\
\hline Lead & 0.922 & 0.00 & 0.922 & \\
\hline Arsenic & 0.254 & 0.426 & 0.535 & \\
\hline Mercury & 0.309 & 0.217 & 0.390 & \\
\hline
\end{tabular}

found for the accumulation of copper, nickel, arsenic and mercury $(p>0.05)$. With respect to the inter-variations between the seasons and the different fish species, no significant differences were obtained $(p>0.05)$.

Most of the respondents were female and all the respondents agreed that they consumed these four fish species regularly. With reference to figure 4 , the percentage of respondents who correctly answered the question about heavy metals is $20 \%$ while $80 \%$ of the respondents wrongly answered this question and therefore do not know what are heavy metals.

\section{Optimisation of digestion protocol and analytical techniques}

The dry ashing procedure was used in this study whereby instead of repetitive oven drying at $135^{\circ} \mathrm{C}$ for 2 hours, freeze drying was used. Wet digestion was avoided due to the risk of reagent contamination, the constant attention requirement and the handling of corrosive acids (Elmer-Parkin Corporation, 1996). The advantages of using a freeze dryer as compared to oven drying include the preservation of the muscle tissue in its original form which can easily be grounded. Charring (partial blackening and burnt surfaces) of samples is also avoided as well as potential loss of metals due to volatilisation during heat application.

The FAAS has detection limits in the range of ppm and high ppb. The levels of Zinc, Copper, Chromium,
Nickel, Cadmium and in several papers, lead, were reported in ppm levels. Igwemmar et al. (2013) obtained levels of zinc in four fishes in the range of 1-3 ppm, levels of copper ranging from 0.00 to $0.3 \mathrm{ppm}$ and levels of lead not detected in ppm in Gwagwalada market, Abuja. Emeka et al. (2014) observed levels of Nickel in fish species to be in the range of 0.00 to $0.30 \mathrm{ppm}$, levels of chromium ranging from 0 to $0.5 \mathrm{ppm}$, levels of cadmium in the range of 0 to $2 \mathrm{ppm}$ and $0 \mathrm{ppm}$ for the detection of mercury in Oguta lake, Nigeria. Levels of Zinc, Copper, Nickel, Chromium and lead (fishes sampled in summer) were successfully detected using the FLAAS.

$\mathrm{Hg}$ and $\mathrm{As}$ were detected using the hydride system after unsuccessful attempts using the FAAS due to the low sensitivity of the FAAS and its detection limits not extending to low ppb. In the FLAAS, only a small portion of the sample is flown through the capillary cell and quickly into the flame. The hydride cell on the other hand, atomises a larger amount of the sample and retain the atomised sample for a greater time span, thereby enhancing the sensitivity of the technique (Parkin Elmer Coorporation, 2013). Arsenic, on the other hand, is thermally decomposed by the application of flames on the hydride cell, reducing arsenic (III) hydride into a gaseous hydride $\mathrm{AsH} 3$ by reaction with sodium borohydride in a hydrochloric acid medium (Behari et al., 2006)

Melek et al., (2006) successfully determined the levels of cadmium (0.09-0.35 mg/kg dry weight) and lead(0.2-0.85) in fish samples using the GFAAS. This finding does not tally with this research whereby lead and 


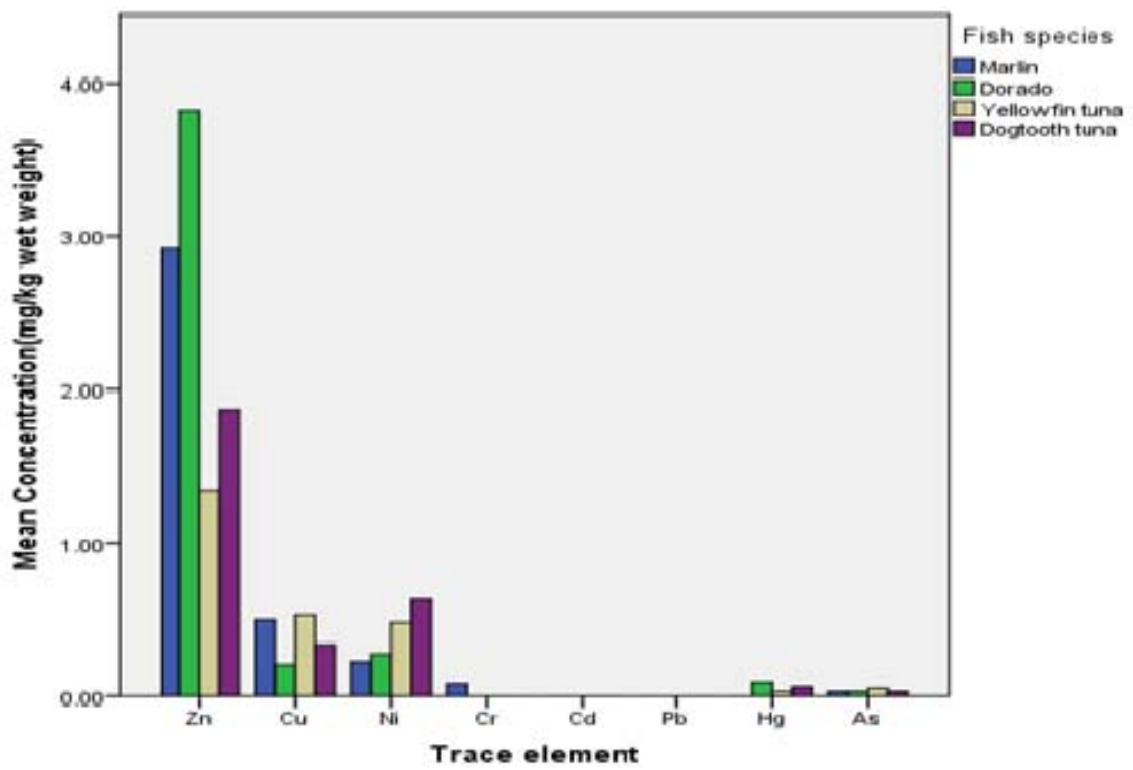

Figure 1. Mean concentration of different trace elements in fish muscles of different fish species for the winter season.

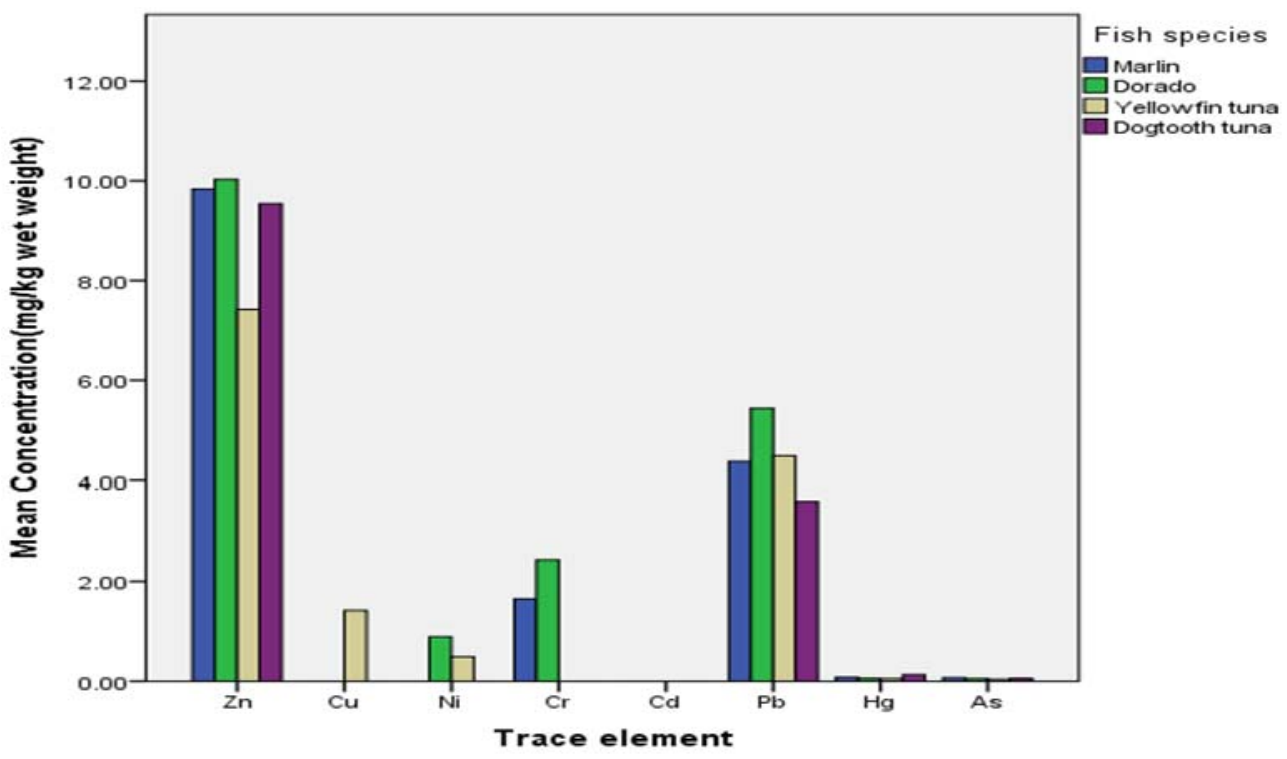

Figure 2. Mean concentration of different trace elements in fish muscles of different fish species for the summer season.

cadmium levels were not detected. This may be due to the use of phosphoric acid as the modifier which affected the analytical results as proposed by Melek et al.,(2006) who stated that the determination of trace elements in fish samples using the GFAAS is difficult due to the interference of a complicated matrix.

\section{Inter-species comparison within elements}

Elemental bioaccumulation in fish is related to two major factors, water through the gills and most importantly food
(Dallinger et al., 1987; Reinfelder et al.,1998; Smith et al., 2002). The bloodstream is the main carrier of metals that circulate and deposit in various tissues. Unfortunately, the tropical zone of the Indian Ocean has not been the focus of researchers in terms of investigating the levels of trace elements in marine organisms (Kureishy et al., 1979; Matthews, 1983; Mwashote, 2003; Robinson and Shroff, 2004 ; Kojadinovic et al., 2006).

The concentrations of the trace elements $\mathrm{Zn}, \mathrm{Cu}, \mathrm{Ni}, \mathrm{Cr}, \mathrm{Cd}, \mathrm{Pb}, \mathrm{Hg}$ and $\mathrm{As}$ are not dependant on the fish species, that is fish species have no significant effect over the accumulation and uptake of the trace elements 


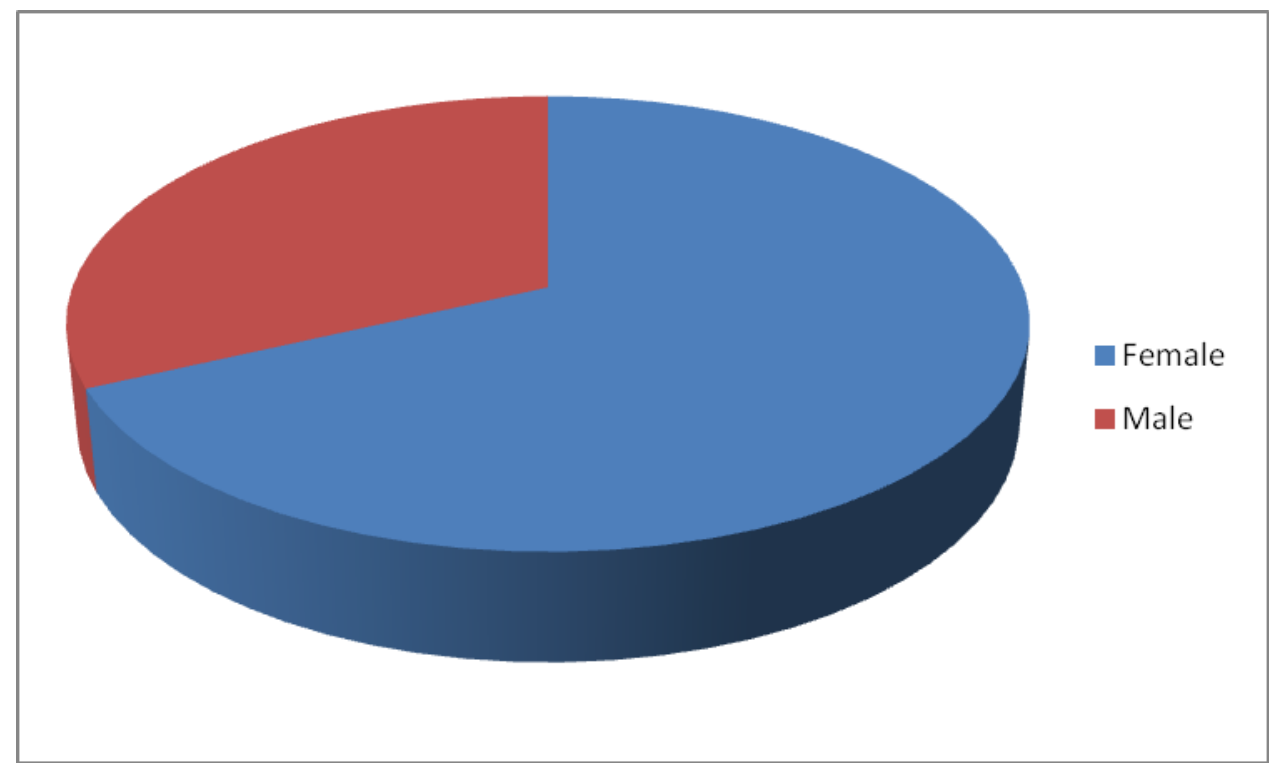

Figure 3. Pie chart illustrating the percentage of male and female respondents filling out the survey form. $68 \%$ of fish buyers were female compared to $32 \%$ of males.

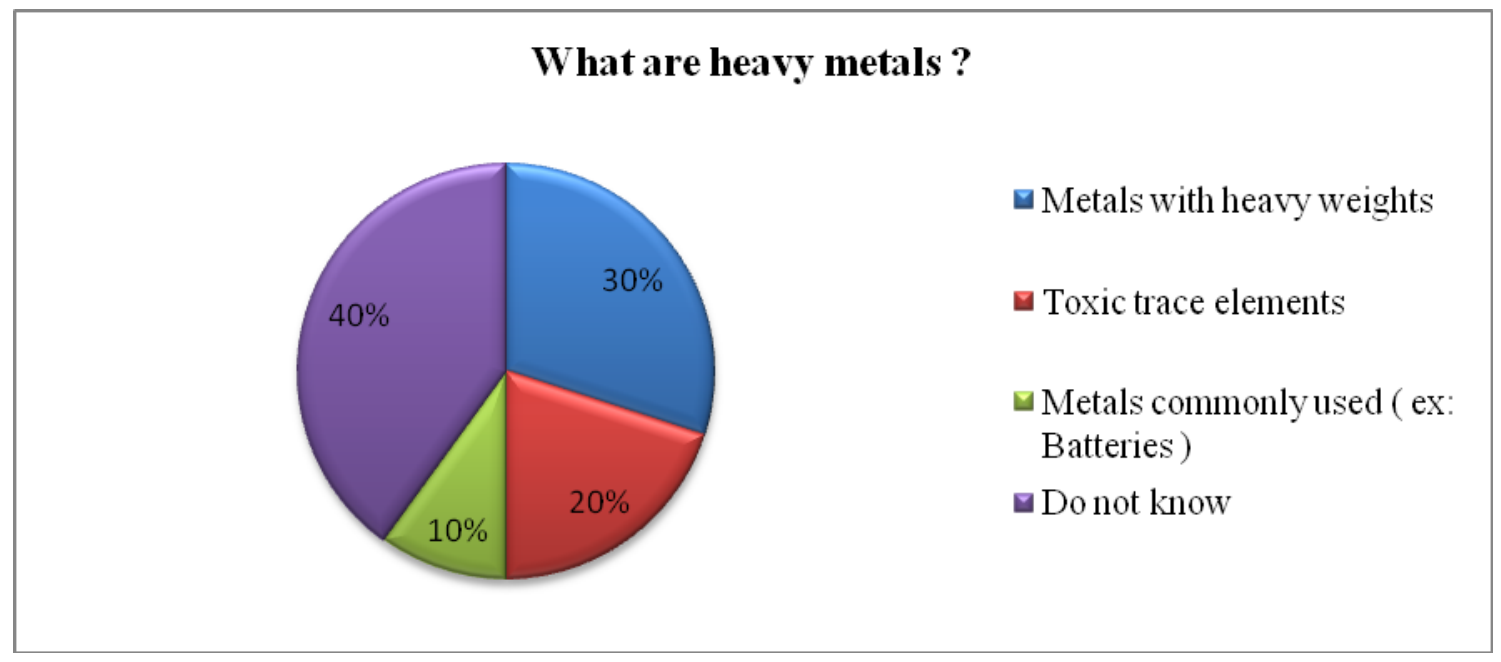

Figure 4 . Pie chart representing the number of respondents choice on the definition of heavy metals

in the muscle tissues of the fishes. These findings do not tally with kalay et al.,(1999) whose research revealed that metals accumulate in muscle tissues of different fish species in significantly different amounts. Moreover, Canli \& Atli (2003) also supported the fact that levels of heavy metals vary in fish species and distinctive aquatic environments.

The difference between this study and the researches mentioned above could be explained by the organisms' size and aquatic environment as proposed by Jalal et al., (2014) who reported a relation between concentration of metal uptake and factors such as fish age, aquatic environment and size. The four fish species in this study were caught in the EEZ of Mauritius, at Riviere Noire fishing point and thereby may live in the same aquatic environment. Furthermore, the fishes caught were approximately of the same size, sampled by preferences of consumers and size availability. This accounts for the homogeneity of the levels of trace elements bioaccumulated in the four species. However, further research need to be conducted to confirm this trend as the sample size used for this study was small $(n=3)$

The levels of zinc $(p=0.00)$, chromium $(p=0.02)$ and lead $(p=0.00)$ accumulated in muscle tissues of the four fish species are significantly different for the summer and winter seasons. The highest levels of the metals are 
Bhoyroo et al. 103

accumulated during the summer season. One possible explanation to these findings is that an increase in the water temperature during summer increases heavy metals uptake in the fishes as compared to the winter season. Ahmed et al., (2013) supported this claim by stating that seasonal variations with regards to the concentration of heavy metals bio-accumulated in fish species follow a trend whereby the highest levels of heavy metals are accumulated during summer while the lowest values are accumulated during winter due to a rise in temperature which favours the uptake of certain heavy metals. The higher water temperature during the summer season as opposed to the lower temperatures during winter, favours a rise in the accumulation uptake and binding of metals probably due to higher metabolic rate in the fishes as proposed by Jezierska et al., (2009). Obasohan \& Eguavoen (2008) also suggested that the rate of pollutant accumulation is favoured during high temperatures as the blood's oxygen affinity is decreased. Khaled( 2004) and Ali \& Abdel (2005) observed a rise in metal concentrations during the warmer months in the tissues of some fish species as well as invertebrates and related this phenomenon to an increase in the organisms' metabolisms due to the higher temperature in summer.

Another possible factor responsible for the differences in accumulation across seasons is the migratory patterns of the four fishes. Beamish et al., (2005) stated that pelagic fish species are highly migratory and the four fish species in this study are pelagic ones. Although present in most oceans, these pelagic fishes constantly migrate especially during the spawning season to warmer waters. Marlins are solitary and highly migratory fishes that are usually found in waters with surface temperatures of 21$33^{\circ} \mathrm{C}$ and yet spend the majority of its lifespan in warm near-surface waters from $25-27^{\circ} \mathrm{C}$ (Tung, 2003). The spawning season for the dolphin occurs mainly in waters above $24^{\circ} \mathrm{C}$ (Potthoff 1971; Palko et al.1982; Farell et al., 2009). Tuna species mature and spawn around the year depending on regions although peak spawning season occurs during August-March ( summer season in Mauritius) as suggested by Jones(1963).

Those four pelagic fishes migrate to warmer waters due to natural preferences or during sprawning season and this could explain the differential accumulation of heavy metals for the two seasons. Fishes caught in winter and summer may therefore come from different marine environments and be subjected to different conditions. Jezierska et al. (2009) suggested that accumulation is dependent on metal concentration, exposure time, route of metal uptake and environmental conditions such as water temperature, $\mathrm{pH}$, salinity and feeding habits. The fishes caught during both seasons may belong to different schools of fish, come from different marine environments and have distinctive conditions proposed by Jezierska et al.,(2009) which would explain the differences in accumulation patterns.

\section{Health-risk assessment for fish consumption}

Safety regulations/guidelines of a country set the MPL ( Maximum permissible level ) of elements present in foodstuffs. In Mauritius, the Food Act 1998, implemented in 2000 sets regulations levels for the presence of heavy metals in foodstuffs such as seafood and fish. Local threshold guidelines can also be compared to international agencies such as WHO (The World Health Organisation) which is an international agency of the United Nations specialised in public health concerns. Other governmental agencies such as the JEFCA (The Joint FAO/WHO Expert Committee on Food Additives), the EC ( European Comission ), the MAFF (Ministry of Agriculture, Fisheries, and Food) in Britain have set MPL ( Maximun permissible level) of trace elements in the human diet as safety regulations. Each agency has threshold levels for a series of elements, both complementary and distinct from the other legislation acts.

In Mauritius, the food act 1998 specifies a tolerable level of zinc at $100 \mathrm{ppm}(100 \mathrm{mg} / \mathrm{l})$. The concentrations of zinc detected in the four fish species lie in the range of 0.1 to $8 \mathrm{mg} / \mathrm{l}$. Therefore, according to Mauritian standards, the tolerable level of zinc in fishes is respected, with observed values being far from the threshold level. Furthermore, the recommended MPL (Maximum Permissible level) for zinc is set at $50 \mathrm{mg} / \mathrm{kg}$ fresh weight in certain countries (MAFF,1995). The highest level of zinc obtained in this study is $10 \mathrm{mg}$ per $\mathrm{kg}$ fresh weight (Table 3.1), which is five times inferior to the threshold levels set internationally. It can therefore be concluded that level of zinc in the four fish species are well below the maximum level indicated both in the Food Act 1998 and MAFF 1995.

Copper is a trace element responsible for the development of bones in the body but can have adverse effects if present in high concentrations (Fraga et al., 2005). The Food Act 1998 specifies a tolerable level of copper at $30 \mathrm{ppm}(\mathrm{mg} / \mathrm{l})$. The concentrations of copper detected in the four fish species range from 0 to 4 $\mathrm{mg} /($ (Figure 3.3) which is well below the threshold of the Food Act 1998. In addition, the MPL for copper in other countries is set at $20 \mathrm{mg} / \mathrm{kg}$ wet weight(MAFF,1995). The concentrations obtained for the analysis of the four fish species in this research lie between 0.2 to $1.4 \mathrm{mg} / \mathrm{kg}$ wet weight which is well below the threshold level set. Therefore, copper levels in the four fish species do not go beyond the local and international threshold levels.

Nickel is present in minute amounts in food, water, soil and air since it is a natural element of the earth's crust (EPA, 1989). There is no MPL set for Nickel in the Food Act 1998 but according to the WHO (1989), the MPL for nickel ranges from 0.5 to $1.0 \mathrm{mg} / \mathrm{kg}$ wet weight in fish muscles. The concentrations of nickel detected in the four fish species range from 0.2 to $0.9 \mathrm{mg} / \mathrm{kg}$ wet weight (Table 3.5). Dorado caught during summer have nickel 
concentration in its muscle tissues $(0.89 \mathrm{mg} / \mathrm{kg}$ wet weight) close to $1.0 \mathrm{mg} / \mathrm{kg}$ wet weight but still lie within the permissible level. Therefore, the concentrations of nickel in all the four fish species lie within the range set by the World Health Organisation.

Chromium is excluded from the Food Act 1998 but according to FAO (1983), the MPL for chromium in fish is $1.0 \mathrm{mg} / \mathrm{kg}$. Marlin (1.7 mg/kg wet weight) and Dorado (2.5 $\mathrm{mg} / \mathrm{kg}$ wet weight) caught during the summer season exceed the authorised level of chromium in muscle tissues according to international standards. However, chromium has several oxidation states, primarily as metallic trivalent, which is found in most foods and nutrient supplements with very low toxicity (Cefalu et al., 2004). The source of chromium in this research is not in the water since chromium originating from contaminated water builds up in the gills rather than in other fish tissues (Sneddon, 2013). Therefore one probable cause of chromium uptake in Dorado and Marlin is in their feeds.

The $\mathrm{WHO}(1989)$ has set the threshold levels for cadmium at $1.0 \mathrm{mg} / \mathrm{kg}$ wet weight and the Food Act 1998 specified permissible cadmium levels of $1.0 \mathrm{ppm}$. Levels of cadmium were not detected in any samples in ppm levels and therefore the levels of cadmium in the four fish species do not represent a health issue according to Mauritian standards.

The Food Act 1998 specifies a tolerable level of lead of $2.0 \mathrm{ppm}(\mathrm{mg} / \mathrm{l})$ in fish. The concentration of lead accumulated in the four fish species during the summer season lies in the range of 0 to $2.0 \mathrm{ppm}$. Some values are very close to the maximum permissible level indicated in the Food Act 1998 and should be closely monitored. Furthermore, $\mathrm{WHO}(1989)$ set the threshold level for lead at $2.0 \mathrm{mg} / \mathrm{kg}$ wet weight and all the four species caught during the summer season have lead concentration beyond the threshold level set (3.60-5.44 $\mathrm{mg} / \mathrm{kg}$ wet weight). Close monitoring of the level of lead in muscle tissues of the four fish species during the summer season should be implemented with a greater number of fish samples to confirm the trend set in this study.

The Food Act 1998 set the acceptable threshold level of mercury in fish tissues at $1.0 \mathrm{ppm}(\mathrm{mg} / \mathrm{l})$. The level of mercury in the four fish species were detected at ppb level and then converted to ppm. The levels of mercury detected in the four fish species lie in the range of 0.02 to $0.71 \mathrm{ppm}$ and therefore do not transgress the Mauritian threshold level. In predatory fish, the most wildly established guideline for mercrury is $1.0 \mathrm{mg} / \mathrm{kg}$ wet weight (IPCS, 1987; EPA, 1994). Fishes caught in the EEZ of Mauritius have levels of mercury in their tissues in the range of 0.03 to $0.1 \mathrm{mg} / \mathrm{kg}$ wet weight which is well below the threshold level set internationally. Thus the four fish species have threshold levels of mercury within the limits set locally and internationally.

The Food Act 1998 specifies level of arsenic at 1.0 ppm ( $\mathrm{mg} / \mathrm{l})$. The level of arsenic in the four fish species were detected at ppb level and then converted to ppm. The level of arsenic accumulated in the four fish species ranges from 0.002 to $0.03 \mathrm{ppm}$ which is far from the threshold level established and therefore do not transgress the Mauritian threshold level. Furthermore, the Joint FAO/WHO Expert Committee (1983) has also set a limit of $0.1 \mathrm{mg}$ per $\mathrm{kg}$ wet weight. The level of arsenic in the fish species ranges from 0.03 to $0.07 \mathrm{mg} / \mathrm{kg}$ wet weight and do not go beyond the international maximum permissible limit. The low levels of arsenic detected can be explained by a limited ability for Arsenic uptake. This hypothesis is supported by Gailer et al. (1995), Lansgton (1984) and Neff (1997) who observed that organisms belonging to the highest trophic levels like predatory fishes have a limited capacity to accumulate arsenic from the water columns as opposed to organisms at the bottom of the food chain such as bacteria, macroalgae and plankton.

\section{Survey analysis ( Awareness of heavy metal bioaccumulation)}

The percentage of female fish buyers represent $68 \%$ of the total respondents. This demonstrates that women are the main fish buyers at local markets. Women are also more vulnerable in the event of heavy metal accumulation in the body since some of the heavy metals such as arsenic, lead, mercury and copper affect the reproductive system of women, more specifically displaying toxicity towards growing foetus (Goeringa et al., 2010). Therefore women, especially during pregnancy are at a greater risk but at the same time, they have the opportunity to determine which fish to buy. They should favour juvenile fishes which accumulates heavy metals to a lesser amount as compared to bigger predatory fishes.

Mauritians are thus good fish consumers and in the case of bio accumulation of heavy metals, this could pose a serious threat if the fishes were to transgress the maximum permissible levels such as lead and chromium in the diet. All respondents replied that they consume dorado, tuna and/or Marlin. This confirms that the fishes sampled in this study are commercially important fishes that are consumed by the general population. Therefore, the fishes selection was the most appropriate and targeted consumers at large.

With reference to figure 4 , the percentage of respondents who correctly answered the question about heavy metals is $20 \%$. The remaining $80 \%$ of the population are not aware of heavy metals at all. This is a serious concern since $82 \%$ of the population affirmed that if according to health studies, the fishes mentioned above could be potentially harmful to their health, they would still consume them. The data shows that the population at large isn't aware of the implications and gravity of the accumulation of heavy metals in fish which is a possible reason why they seem unconcerned about 
the possible health effects during fish consumption. If made aware, then perhaps peoples' opinions would change and they would become more health conscious. Proper sensitisation campaigns are a good stepping stone in aiding the population's awareness of the implications of heavy metals in the body.

\section{CONCLUSION AND RECOMMENDATIONS}

In this present study, the level of trace elements $(\mathrm{Zn}, \mathrm{Cu}, \mathrm{Ni}, \mathrm{Cr})$ and heavy metals $(\mathrm{Pb}, \mathrm{Hg}, \mathrm{Cd}, \mathrm{As})$ were analysed in the muscle tissues of four commercially important fish species. Inter-species variations with respect to elemental accumulations were not significantly different while seasonal variations for the accumulation of $\mathrm{Cr}, \mathrm{Zn}$ and $\mathrm{Pb}$ were significantly different and attributed to the migratory nature of the fishes as well as a rise in the water temperature during summer which results in high metabolic rate and metal uptake. Marlin $(1.7 \mathrm{mg} / \mathrm{kg}$ wet weight) and Dorado ( $2.5 \mathrm{mg} / \mathrm{kg}$ wet weight) caught during the summer season exceed the authorised level of chromium in muscle tissues according to international standards. Furthermore, lead accumulated during summer seasons were very close to the maximum authorised threshold level according to the Food Act 1998 and transgressed the threshold for the WHO. In conclusion, the fish species studied can be considered safe for consumption with close monitoring required for summer catches with respect to the level of lead and chromium and further studies are required to confirm this trend.

Periodical monitoring of heavy metals in commercial fishes are needed for safety evaluations and environmental water quality should be assessed. Other similar studies have to be conducted with a greater number of fish samples to confirm the trend set in this study. The Food Act 1998 should be revised to include threshold levels for a greater number of heavy metals especially chromium since the latter exceeded international boundaries and should be compared with agencies such as the WHO and the MAFF. Sensitisation campaigns should be carried out to inform the general population about the risk of heavy metals toxicity. Gynaecologists should be encouraged to inform patients about the risk of eating certain fish (heavy metal bioaccumulators) that can affect foetal growth.

\section{ACKNOWLEDGEMENTS}

This project was funded by the University of Mauritius. We thank Dr. Daniel Marie of The Mauritius Oceanography Institute for kindly assisting in Freeze drying.

\section{REFERENCES}

Ahmed Th, A Ibrahim, Hossam M Omar(2013). Seasonal variation of heavy metals accumulationin muscles of the African Catfish
Clarias gariepinus and in River Nile water and sediments at Assiut Governorate, Egypt. Journal of Biology and Earth Sciences, 3(2), 236-248.

Ali M, Abdel-Satar A(2005). Studies of some heavy metals in water, sediment, fish and fish diets in some fish farms in El-Fayoum province. Egypt J Aquat Res. 31 (2): 261 -273.

Alina M, Azrina A, Mohd Yunus, AS, Mohd Zakiuddin S, Mohd Izuan Effendi H, Rizal MR(2011). Heavy metals (Mercury, Arsenic, Cadmium, Plumbum) in selected marine fish and shellfish along the Straits of Malacca. International Food Research Journal, 19 (1), 135-140.

Bashir FH, Othman MS, Mazlan AG, Rahim SM, Simon KD(2013). Heavy metal concentration in fishes from the coastal waters of Kapar and Mersing, Malaysia. Turkish Journal of Fisheries and Aquatic Sciences, 13(2)

Beamish RJ, McFarlane GA, King JR(2005). Migratory patterns of pelagic fishes and possible linkages between open ocean and coastal ecosystems off the Pacific coast of North America. Deep Sea Research Part II: Topical Studies in Oceanography, 52(5), 739755.

Behari JR, Prakash R(2006). Determination of total arsenic content in water by atomic absorption spectroscopy (AAS) using vapour generation assembly (VGA). Chemosphere, 63(1), 17-21.

Berlin M, Blanks R, Catton M, Kazantzis G, Mottet Nk, Sumiuallah $Y(1992)$. Birth weight of children and cadmium accumulation in placentas of female nickel- cadmium(long life) battery workers.Lyon : International Agency for Reseach on Cancer (IARC), 118, 257-62.

Bloom NS(1992). A survey of size-specific mercury concentrations in game fish from Maryland fresh and estuarine waters. Arch. Environ. Contam.Toxicol.,39 (1), 53-59.

Business Mega (2012). Fishing Industry: When Self-Sufficiency in Fish? Mauritius/Agro and Food. http: //business.mega .mu/2 012/08/02/ fishing-industry-when-self-sufficiency-fish/ [Last accessed : 01 March 2015]

Business Mega (2014). Seafood Hub: Investment of Rs 40 Billion in 2014. Mauritius/Agro and Food. http:/business.Mega .mu/2014/01/ 24/seafood-hub-investment-rs-40-billion-2014/ [Last accessed : 01 March 2015]

Canli, M., \& Atli, G. (2003). The relationships between heavy metal (Cd, $\mathrm{Cr}, \mathrm{Cu}, \mathrm{Fe}, \mathrm{Pb}, \mathrm{Zn}$ ) levels and the size of six Mediterranean fish species.Environmental pollution, 121(1), 129-136.

Cefalu WT, Hu FB(2004). Role of chromium in human health and in diabetes.Diabetes Care, 27(11), 2741-2751.

Colette BB, Nauen CE(1983). Scombrids of the world. An annoted and illustrated catalogue of tunas, mackerels, bonitos and related species known to date. FAO Fisheries Synopsis 2(125),140.

Dallinger R, Prosi F, Segner H, Back H(1987). Contaminated food and uptake of heavy metals by fish: a review and a proposal for further research.Oecologia, 73 (1), 91-98.

Dianne J, Bray (2011). Mahi Mahi, Coryphaena hippurus, in Fishes of Australia.http: //www. Fishes ofaustralia .net.au /home/species/1730 [ Last accessed on : 20 January 2015]

Dietz R, Riget F, Johansen P(1996). Lead, cadmium, mercury and selenium i Greenland marine animals. Sci. Tot. Environ., 186, 6793.

Elnabris KJ, Muzyed SK, El-Ashgar NM(2013). Heavy metal concentrations in some commercially important fishes and their contribution to heavy metals exposure in Palestinian people of Gaza Strip (Palestine). Journal of the Association of Arab Universities for Basic and Applied Sciences, 13(1), 44-51.

Emeka U(2014). Assessment of Water Quality and Heavy Metal levels of Fish Species in Oguta Lake, Imo State Nigeria. Journal of Natural Sciences Research, 4(8), 103-112.

Environmental Protection Agency (EPA) (1986).Nickel Compounds

http://www.epa.gov/airtoxics/hlthef/nickel.html [ Last accessed : 26 December 2014]

Environmental Protection Agency (EPA) (1994). Guidance for assessing chemical contaminant data for use in fish advisories. Risk assessment and fish consumption limits, 2.

Farell $E R(2009)$. The Habitat, Movements, and Management of Dolphin, Coryphaena hippurus, in the Western North Atlantic, Caribbean, and Gulf of Mexico .http:// dukes pace. lib. duke. edu/ 
dspace/bitstream/handle/10161/969/Farrell MPFinal.p df..?sequ ence=1 [Last accessed : 28 December 2014]

FAO(1983). Compilation of Legal Limits for hazardous substances in fish and fishery products. FAO Fishery circular no. 464. 5-100.

Fraga CG(2005). Relevance, essentiality and toxicity of trace elements in human health. Molecular aspects of medicine, 26(4), 235-244.

Gailer J, Francesconi KA, Edmonds JS, Irgolic KJ (1995). Metabolism of arsenic compounds by the blue mussel Mytilus edulis after accumulation from seawater spiked with arsenic compounds. Appl Organomet Chem, 9, 341-355.

Gilmour CC, Riedel GS(2000). A survey of size-specific mercury concentrations in game fish from Maryland fresh and estuarine waters. Arch.Environ. Contam. Toxicol., 39 (1), 53-59.

Goeringa P.L. and Barber D.S.(2010). Hepatotoxicity of Copper, Iron, Cadmium, and Arsenic.Comprehensive Toxicology, 9,501-526.

Haynes D , Johnson JE(2000). Organochlorine, heavy metal and polyaromatic hydrocarbon pollutant concentrations in the Great Barrier Reef (Australia) environment: a review. Marine Pollution Bulletin, 41(7-12), 67-278

Igwemmar NC, Kolawole SA, Odunoku SO(2013). Heavy Metal Concentration in Fish Species Sold In Gwagwalada Market, Abuja. International Journal of Science and Research, 2(11), 7-8.

IPCS (1987). Principle for safety assessment of food additives and contaminants in food. Tech. rep., International Programme on Chemical Safety in cooperation with the Joint FAO/WHO Expert Committee on Food Additives (JECFA).

Islam MS \& Tanaka M. (2004). Impacts of pollution on coastal and marine ecosystems including coastal and marine fisheries and approach for management: a review and synthesis. Marine Pollution Bulletin, 48 ,624-649

Jaffar M, Ashraf $M(1988)$. Selected trace metal concentrations in different tissues of fish from coastal waters of Pakistan (Arabian Sea). Indian J. Mar.Sci. 17, 231-234.

Jalal KCA, Mohd AY, Habab M, Kamaruzzaman BY (2014). Bioaccumulation of selected metals in fresh water Haruan fish (Channastriatus) collected from Pahang river basin, Malaysia. Oriental Journal of Chemistry, 29(4).

Jarup L, Berglund M, Elinder CG, Nordberg G, Vanter M(1998). Health effects of cadmium exposure-a review of the literature and a risk estimate. Scandinavian journal of work, environment \& health, 1-51.

Jezierska B, Ługowska K, Witeska M(2009). The effects of heavy metals on embryonic development of fish (a review). Fish physiology and biochemistry, 35(4), 625-640.

Joint FAO/WHO Expert Committee on Food Additives [ JECF A] (1983 ). Evaluation certain food additives and contaminats. World Health Organisation Technical Report Series, 696,pp 20.

Jones S, Silas EG(1963). Tuna and tuna-like fishes from the Indian seas. FAO Experience Paper 43, 3(6), 1775-1796.

Kalay M, Aly O, Canil M (1999). Heavy metal concentration in fish tissues from the Northeast Mediterranean Sea. Bull. Environ. contam. Toxicol., 63,673-8.1

Khaled $A(2004)$. Heavy metals concentrations in certain tissues of five commercially important fishes from El-Max bay, Alexandria, Egypt. Egypt J Aquat Biol Fish. 8(1), 51 -64.

Kojadinovic J, Potier M, Le Corre M, Cosson RP, Bustamante $P(2007)$. Bioaccumulation of trace elements in pelagic fish from the Western Indian Ocean. Environmental Pollution, 146(2), 548-566.

Kraepiel AML, Keller K, Chin HB, Malcolm EG, Morel FMM(2003). Sources and variations of mercury in tuna. Environ. Sci. Tech., 37 (24), 5551-5558.

Kumar B, Sajwan KS, Mukherjee DP. (2012). Distribution of heavy metals in valuable coastal fishes from North East Coast of India. Turkish Journal of Fisheries and Aquatic Sciences, 12, 81-88.

Kureishy T W, George MD, Sen Gupta R(1979). Total mercury content in some marine fish from the Indian Ocean. Mar. Poll. Bull.,10, 357360.

Lansgton WJ (1984). Availability of arsenic to estuarine and marine organisms: a field and laboratory evaluation. Mar Biol, 80, 143154.

Mackay NJ, Kazacos MN, Williams RJ, Leedow MI(1975). Selenium and heavy metals in black marlin. Mar. Poll. Bull. 6 (4), 57-61.
MAFF, (1995). Monitoring and surveillance of non-radioactive contaminants in the aquatic environment and activities regulating the disposal of waste at sea, 1993. Aquatique Environment Monitoring Report No. 44. Technical Report. Directorate Fisheries Research, Lowestoft, UK.

Matthews AD (1983). Mercury content of commercial important fish of the Seychelles, and hair mercury levels of a selected part of the population. Environ. Re,. 30, 305-312.

Melek E, Tuzen M, Soylak $M(2006)$. Flame atomic absorption spectrometric determination of cadmium (II) and lead (II) after their solid phase extraction as dibenzyldithiocarbamate chelates on Dowex Optipore V-493. Analytica chimica acta, 578(2), 213-219.

Ministry of Health and Quality of Life (1998), Food Act, Ministry of Health and Quality of Life, Mauritius. Available at : www .food scipress.com/JFL82.htm. [ Last accessed : 21 March 2015]

Moberg Wing A, Wing K, Tholin K, Sjostrom R, Sandstrom Hallmans $G(1992)$. The relationof the accumulation of cadmium in human placenta to the intake of high fibre grains and maternal iron status. Eur G Clin Nutr, 46, 58595.

Mwashote BM(2003). Levels of cadmium and lead in water, sediments and selected fish species in Mombasa, Kenya. Western Indian Ocean J. Mar. Sci, 2(1), 25-

34.

Naji A, Ismail A, Ismail AR(2010). Chemical speciation and contamination assessment of $\mathrm{Zn}$ and $\mathrm{Cd}$ by sequential estraction in surface sediment of Klang River, Malaysia. Microchemical Journal, 95, 285-292.

Neff JM (1997) .Exotoxicology of arsenic in the marine environment. Environ Toxicol Chem, 16, 917-927

Nwoko CIA, ukiwe LN, egereonu UU, ukachukwu SN(2014). Seasonal variation of heavy metals concentrations in fish in Oguta lake, Nigeria. Journal of advances in chemistry, 10(7), 2929-2936.

Obasohan EE, Eguavoen OI (2008). Seasonal variations of bioaccumulation of heavy metals in a freshwater fish (Erpetoichthys calabaricus) from Ogba River, Benin City, Nigeria. African Journal of General Agriculture, 4(3), 153-163.

Palko BJ, Beardsley GL, Richards W (1982). Synopsis of the biological data on dolphin-fishes. Coryphaena hippurus Linnaeus and Coryphaena equiselis Linnaeus.http://www.fao.org/ docrep/0 17 lap934e/ap934e.pdf [ Last accessed : 28 December 2014]

Parkin- Elmer (2013). Atomic spectroscopy: a guide to selecting the appropriate technique and system.http://www.Perkinelme r.com / PDFs/Downloads/BRO WorldLeaderAAICPMSI [Last Accessed: 26 December 2014]

Parkin- Elmer (1996). Atomic absorption spectroscopy analytical methods. The Perkin Elmer Corporation, 132-145.

Potthoff, T (1971). Observations on two species of dolphin (Coryphaena) from the tropical Mid-Atlantic. Fishery Bulletin,69,877-879.

Raja P, Veerasingam S, Suresh G, Marichamy G, Venkatachalapathy $R$ (2009). Heavy metals concentration in four commercially valuable marine edible fish species from Parangipettai Coast, South East Coast of India. International Journal of Animal and Veterinary Advances,1 (1), 10-14.

Reinfelder JR, Fisher NS, Luoma SN, Nichols JW, Wang W.-X(1998). Trace element trophic transfer in aquatic organisms: A critique of thekinetic model approach. Sci. Total Environ., 219 (2-3), 117-135.

Robinson J, Shroff J(2004). Observations on the levels of total mercury $(\mathrm{Hg})$ and selenium $(\mathrm{Se})$ in species common to the artisanal fisheries of Seychelles.Seychelles Med. \& Dental J, 7 (1), 56-60.

Shanker AK(2008). 21 Mode of Action and Toxicity of Trace Elements. http://www.agriculture.frih.net/c21.pdf [Last accessed: 29 December 2014]

Smith JT, Kudelsky A V, Ryabov IN, Daire SE, Boyer L, Blust RJ, Fernandez JA, Hadderingh RH, Voitsekhovitch OV(2002).Uptake and elimination of radiocaesium in fish and the "size effect". J.Environ. Radioactiv. 62 (2), 145-164.

Sneddon Charles (2013).Chromium and its negative effects on the environment.http://serc.Carleton.edu/NAGTWorkshops /health / case studies/chromium.html [ Last accessed : 31 May 2015]

Stafford CP, Haines, T. A., (2001). Mercury contamination and growth rate in two piscivore populations. Environ. Toxicol. Chem., 20, 2099-2101. 
Tepe Y, Türkmen M, Türkmen A( 2008). Assessment of heavy metals in two commercial fish species of four Turkish seas. Environmental Monitoring Assessment, 146,227-284

Tung L(2003). Makaira nigricans (Blue marlin) .http: //an imal diversity .org/accounts/Makaira nigricans/ [Last accessed : 21 December 2014]

Türkmen A, Türkmen M, Tepe Y, Akyurt I (2005). Heavy metals in three commercially valuable fish species from Iskenderun Bay,
Northern East Mediterranean Sea, Turkey. Food Chemistry, 91,167172

Uluturhan E, Kucuksezgin $F(2007)$. Heavy metal contaminants in Red Pandora (Pagellus erythrinus) tissues from the Eastern Aegean Sea, Turkey. Water Research, 41, 1185-1192.

WHO (1989). Heavy metals-environmental aspects. Environment Health Criteria. No. 85. Geneva, Switzerland. 